\title{
EL HORROR INVISIBLE Y EL HORROR EN ESCENA. LA PULSIÓN RAPSÓDICA EN APRÈS MOI, LE DÉLUGE, DE LLUÏSA CUNILLÉ, Y EN Y COMO NO SE PUDRIÓ...: BLANCANIEVES, DE ANGÉLICA LIDDELL
}

\author{
INVISIBLE HORROR AND HORROR ON STAGE. APRÈS MOI, \\ $L E$ DÉLUGE, BY LLUÏSA CUNILLÉ, AND Y COMO NO SE \\ PUDRIÓ...: BLANCANIEVES, BY ANGÉLICA LIDDELL
}

\author{
Ana PRIETO NADAL \\ Grupo de Investigación del SELITEN@T \\ ana_prieto_nadal@hotmail.com
}

Resumen: El compromiso del teatro con la realidad puede abordarse de múltiples maneras. Nos proponemos analizar dos propuestas dramatúrgicas radicalmente distintas - antitéticas - alrededor del tema de la hambruna y los niños soldados en África, y constatar las formas que en ellas adopta la pulsión rapsódica propia del drama contemporáneo. Après moi, le déluge, de Lluïsa Cunillé, opta por personajes europeos y por la palabra como catalizadora de la acción, mientras que Angélica Liddell, en $Y$ como no se pudrió...: Blancanieves, presenta a sus personajes ya inmersos en la barbarie. 
Abstract: The theatre commitment with reality can be carried out in many ways. We set out to analyze two radically different - antithetical - proposals about the subject of famine and soldier children in Africa, and to state the forms that rhapsodic impulse, typical of contemporary drama, adopt in them. Après moi, le déluge, by Lluïsa Cunillé, opts for European characters and the word as catalyst of action, while in $Y$ como no se pudrió.... Blancanieves, by Angélica Liddell, the characters are already immersed in the barbarism.

Palabras clave: Lluïsa Cunillé. Après moi, le déluge. Angélica Liddell. $Y$ como no se pudrió...: Blancanieves. Horror. Epicidad. Pulsión rapsódica. Teatro español.

Key Words: Lluïsa Cunillé. Après moi, le déluge. Angélica Liddell. Y como no se pudrió...: Blancanieves. Horror. Epicity. Rhapsodic impulse. Spanish Theatre.

¿Y si nada les puede conmover? Ese es el ganglio ardiente que no deja de estrangular la garganta del autor que, como un filósofo decepcionado, se siente incapaz de resolver la paradoja entre el lenguaje y la catástrofe humana, entre el lenguaje y la necedad. El autor se plantea el acto teatral como un esfuerzo de comunicación moral, un desafío a la sensibilidad del espectador, una llamada al conocimiento.

Angélica Liddell, Poética teatral.

\section{INTRODUCCIÓN}

El teatro - el arte - se pone a veces al servicio de la denuncia, bien por una necesidad íntima e inaplazable del artista, bien como una faceta más de la labor creadora y de su vivisección de la realidad.

En 2004 Lluïsa Cunillé recibió, en calidad de autora residente del Teatre Lliure, el encargo de escribir una obra basada en un informe de la FAO sobre la hambruna y la mortalidad infantil en el mundo. De ahí, salió Après moi, le déluge. Después de su estreno en 2007 en el Teatre Lliure, con dirección de Carlota Subirós, fue llevada al Teatro Valle-Inclán de Madrid. La obra delata con precisión psicológica y política la ferocidad del colonialismo. La cita introductoria de Joseph Conrad, de la obra Heart of Darkness, es significativa y reveladora: «Los hombres que vienen aquí no deberían tener entrañas». 
Señala Benach en su crítica (2007: 52) que «la autora vinculó la propuesta a los fundamentos estructurales de la calamidad, alejando el tema de toda lectura filantrópica o del argumentario de la mejor ONG».

El caso de Angélica Liddell es radicalmente distinto. En $Y$ como no se pudrió.... Blancanieves - estrenada en 2005 en La Fundición, de Bilbao-, como en otras piezas de esta etapa, se concreta el horror sobre un escenario. Se pone en manos del arte el grito de una niña soldado, una niña violada. Se recupera la dignidad de la palabra denuncia y se la concilia con el arte. Es un grito furioso contra la guerra y la pobreza a partir de la situación de los niños en algunas de las regiones menos favorecidas del planeta.

El comercio ilegal internacional de recursos tan codiciados como el petróleo, los diamantes o el coltán ha traído aparejada la financiación de conflictos armados en países como Sudán, Angola, Sierra Leona o el Congo; ésta es la cuestión tratada por Cunillé, que sitúa su obra Après moi, le déluge en Kinshasa, en el Congo. Por su parte, Liddell, en $Y$ como no se pudrió: Blancanieves, no se centra en un país concreto ni en una determinada tipología de conflicto, sino que aborda, por encima de fronteras y determinismos locales, la cuestión de los niños soldados, que son más de 300.000 en todo el mundo, en más de veinte países; focaliza además en la cuestión del género, al poner en escena una niña soldado víctima de repetidos abusos sexuales. Tanto Lluïsa Cunillé como Angélica Liddell se documentan exhaustivamente para abordar esta temática.

Una realidad como ésta - «yo no pretendo escandalizar, el escándalo está en la realidad», dirá Liddell (Cornago, 2005: 320) - puede ser abordada desde muchos ángulos. Cunillé optará por un mecanismo de omisión extremo, la invisibilidad - la incorporeidad - de un personaje en escena, mientras que Angélica Liddell encenegará en el horror y la barbarie a un personaje de cuento infantil, Blancanieves.

\section{FILIACIONES Y RECURSOS TEATRALES}

Resulta casi imposible concebir dos actitudes creadoras más opuestas que las de estas dos dramaturgas. Lluïsa Cunillé ha optado desde el principio por no hablar con los medios de comunicación, acaso como un modo de posicionarse ante ellos; Angélica Liddell se sirve de los medios - fundamentalmente de la prensa escrita y de entrevistas o estudios especializados - para explicar su obra, se autodefine como autora kamikaze (Cornago, 2005: 320) y milita en un teatro de la provocación explícita. 
Cunillé suele partir de la cotidianidad, de la anécdota, para de pronto mostrar una brecha por donde se cuela un vislumbre de sublimidad o de gravedad - lo ignoto, lo trágico, lo apocalíptico- - Liddell habla desde la feroz afirmación del individuo, a través de una poetización violenta que afecta no sólo a la palabra, sino también al cuerpo y al espacio escénico.

Liddell se sitúa más allá de la ficción, ataca la realidad histórica, política y social del espectador en un tono visceral y exasperado, con acciones físicas poéticas y violentas, alcanzando de manera directa la sensibilidad del espectador. Cunillé trabaja desde un mimetismo de lo pequeño, un mimetismo engañoso con una línea de fuga que promete una visión imprevista; aplicando la lente de aumento a los mecanismos de relación, alcanza una privilegiada percepción del instante, la fijación del tiempo en una minúscula porción del espacio íntimo.

El lenguaje de Cunillé se articula a partir del modelo del lenguaje cotidiano, aunque dirigido a crear un determinado efecto. Se trata, según Puchades (2005: 31), de un «teatro conversacional emitido en una situación enunciativa extrañada espacio-temporalmente y por un emisor que tiende a la fragmentación, que responde a un instinto de teatralidad que (re)ficcionaliza constantemente lo que dice»; el lenguaje tiene en algunas ocasiones repuntes poéticos, pasando del silencio y laconismo a la frase preñada de significación y lirismo; alternando entre un registro cotidiano y otro más poético. Por su parte, Liddell emplea un lenguaje estilizado - deformado - y monólogos verborreicos, devastadores, en que la voz íntima del personaje lo ocupa todo, obviando la fábula pero sin menoscabar el conflicto dramático.

Veamos cómo estas dos autoras - de cuyas respectivas dramaturgias se ha ocupado en diversas ocasiones el SELITEN@T (Romera Castillo, 2011: 389-392) - abordan el tema de la guerra y la hambruna, y la situación de los niños en países sometidos a un interminable ejercicio de violencia.

\subsection{Après moi, le déluge}

En la dramaturgia de Lluïsa Cunillé se opera una suerte de introspección sobre la realidad, la cotidianidad y la intimidad. Ordóñez (1998: 43) sostiene que el tema de Cunillé es lo misterioso e inaprehensible del alma, la ambigüedad extrema de la percepción. La realidad es extraña y la verdad se escurre volátil, contradictoria, fragmentaria.

Algunos de sus diálogos pueden parecer interrogatorios, pero acaban 
conduciendo al monólogo revelador del personaje; otros fluyen a través de la narración de casos y anécdotas. La autora juega con las palabras creando un sutil distanciamiento. Del espectador depende el posicionamiento ético que comprenda o decida el final de las obras. Más que ideas, los diálogos de Lluïsa Cunillé aportan sensaciones y recurrencias no evidentes, así como algunas historias dignas de alojarse en la memoria del receptor, y ello en virtud del tempo lento con que evolucionan las intervenciones, que realza cada frase y hace brillar elementos a priori anodinos para traerlos nuevamente al recuerdo y revestirlos de una nueva significación. En este sentido, señala Barbero Reviejo (2005: 271), que «El intimismo, el peso de un enigma que soporta cada personaje, el papel del azar y de la memoria, el significado de los objetos más triviales enredados en el discurrir de los días, la incomunicación» son los materiales con que trabaja Cunillé.

Se cuentan como recursos extrañadores los inesperados giros en los temas de la conversación, giros sorpresivos - aunque virtuosamente integrados dentro de la particular lógica teatral de la autora - que crean un ritmo no sólo sonoro, sino también de contenidos. También los silencios se cargan de emociones, significan. Estas continuas alternancias y variaciones entre silencio y voz, de temas que se abandonan y se recuperan, entre diálogos y monólogos, van componiendo una especie de partitura.

Espacialmente situada en un África invisible, en la habitación de un hotel de Kinshasa (actual República democrática del Congo), y temporalmente referida al período posterior a la salida del gobierno del presidente Mobutu, Après moi, le déluge muestra una actitud ética y un compromiso ideológico maduro, alejado de aspavientos aleccionadores. La atraviesan y hacen posible dos personajes visibles y uno invisible. Un hombre de negocios que trafica con coltán, mineral con que se fabrican desde móviles a misiles nucleares, y una intérprete que habla quince idiomas, en especial los dialectos africanos, y que, empecinada en tomar el sol, no sale de la zona hotelera. El traficante, que en su lejana juventud había sido pintor en París, se halla ahora enfermo, tiene el cuerpo lleno de cicatrices y posee una pistola, una Beretta con una sola bala que le dio un amigo tras abandonarle en la selva. A pesar de algunas confidencias extemporáneas, ambos son seres desarraigados, de parlamentos deliberadamente vagos y ambivalentes, trufados de tópicos. Desde su posición de privilegio, los dos personajes occidentales se han procurado un blindaje contra la propia conciencia. El interrogatorio al que el traficante somete a la mujer está a medio camino entre lo cortés, con tintes banales, y lo inquietante. El desinterés y la apatía constituyen la particular coraza que la intérprete se ha construido para sobrevivir, manteniéndose 
atrincherada en una amnesia y frivolidad deliberadas:

HOMBRE.- ¿Por qué se divorció?

INTÉRPRETE.- Mi marido me dejó.

$[\ldots]$

INTÉRPRETE.- ¿Sabe que me dijo antes de dejarme?

HOMBRE.- Qué le dijo...

INTÉRPRETE.- Después de mí, el diluvio.

[...]

Hombre.- Es lo mismo que dijo Mobutu cuando el golpe de estado, antes de dejar el país (Cunillé, 2011: 199-200).

Después, la intérprete deberá traducir las palabras del recién llegado, el hombre misterioso al que esperaban. Se trata de un africano viejo, de un poblado del norte. Como el traficante, también está enfermo, y ha venido hasta esa habitación de hotel para proponer un último negocio. Pero el espectador no lo ve: ése es el truco de la obra. El viejo entiende el idioma del traficante pero no puede hablarlo, porque sólo habla en kiluba; la intérprete se convertirá en su voz $-\mathrm{y}$, a ojos de los espectadores, también en su cuerpo- - El africano pone reparos en que su intérprete sea una mujer, pero acaba accediendo con la condición de que ésta no lo mire mientras traduce; es decir, que no mire la butaca vacía donde está el personaje invisible.

El africano pide una vida nueva para su hijo en el opulento primer mundo, e insiste en que el hombre de negocios se lo lleve a Europa, como músico, como chófer, como guardaespaldas, como enfermero; lo que sea. El hombre de negocios rehúye implicarse y le ofrece un trabajo en la extracción de coltán en el Congo. El africano, que no está dispuesto a que su hijo se quede en África, explica cómo el chico fue secuestrado por la guerrilla y obligado a luchar y a matar. El africano habla de las cosas estremecedoras que le ha contado su hijo de la guerra:

HOMBRE.- Y qué más le ha contado...

INTÉRPRETE.- ¿Mi hijo? Cosas que le horrorizarían [...] Entraban en cualquier lugar que les ordenaban y disparaban a todo el mundo que se pusiera delante, y a los que quedaban vivos les cortaban las manos, especialmente a los soldados, para que les tuvieran miedo. A algunos soldados incluso les arrancaban los ojos y el corazón, los cocinaban y luego se los comían. Vio- 
laban a todas las mujeres que les gustaban y se las llevaban con ellos $(\mathrm{Cu}-$ nillé, 2011: 221-222).

En un momento dado, el africano parece desistir ante la impaciencia y cerrazón del hombre de negocios, pero no es más que una estrategia; hace amago de irse - el cuerpo de la intérprete, poseída por el africano, se levantapero luego vuelve a la carga y ensalza repetidamente las cualidades de su hijo. Es tanta la insistencia del anciano que el traficante acaba cediendo. Quiere conocer al hijo. Le pide al africano que lo haga subir a la habitación del hotel, porque desea hablar directamente con él:

Hombre.- Es posible que pueda darle un trabajo.

Intérprete.- ¿Quiere que trabaje para usted?

[...]

Hombre.- Sí que le necesito. (Pausa larga.) ¿Quiere que llame a recepción para que le avisen?

Intérprete. - ¿A mi hijo?

[...]

Hombre.- ¿Dónde está entonces?

Intérprete.- En ninguna parte. Mi hijo murió hace dieciséis años (Cunillé, 2011: 241-242).

El africano replica que su hijo murió a los tres años, como consecuencia de una mala cosecha; contrajo malaria y murió. Ésta es la pirueta final del viejo, la broma macabra. ¿Por qué ha llevado las cosas hasta ese límite? ¿Qué pretende? ¿Acaso reírse de la superioridad blanca, de su dadivosidad afectada?

INTÉRPRETE. [...] Si mi hijo aún estuviera vivo habría vivido todo lo que le he contado. Ni siquiera yo, su padre, habría podido ahorrarle nada de todo lo que le esperaba. (Pausa.) Todos estos años sólo le hemos echado de menos su madre y yo, y desde hace cuatro años solamente yo. Pero ahora usted también le echará de menos cuando vuelva a Ciudad del Cabo.

HoMBRE.- ¿Por eso ha venido a verme?

[...]

INTÉRPRETE.- He venido para poder oír decir a alguien que necesitaba a mi hijo y estar completamente seguro de que alguien más que yo lo echaría de menos (Cunillé, 2011: 242). 
No ser el único depositario de la pérdida del hijo. Avivar por un momento, efímero y huidizo, la conciencia europea, la culpa, denunciar la impasibilidad. La voluntad profunda es crear malestar, abrir la herida de la mala conciencia. El africano lo ha elegido precisamente a él porque le ha parecido el más difícil, el hombre de negocios más duro e implacable, y también el mejor negociante. ¿Acaso el más blindado? Ha querido agujerear su coraza, herirlo, importunarlo.

El hombre de negocios echa al africano de la habitación y se acaba el trance de posesión. El africano se va y la intérprete recupera su ser, su carácter huidizo, su amnesia. El hombre de negocios la invita a cenar; ella rehúsa, con la excusa de tomar el sol antes de la cena, pues el sol - puntuali$\mathrm{za}-$ es lo único seguro que hay en Kinshasa.

¿Verdad o mentira? ¿Realidad o ficción? Ficción y verdad. Se impone la necesidad de contar la identidad del africano para que el espectador repare en su existencia, una existencia a la que no se le asigna personaje en escena, sino que depende del hilo de la palabra que todo lo enhebra y todo lo ocupa. La materialidad de la palabra no logra corporeizar la realidad - ni siquiera al personaje - , pero sí dar cuenta de la conciencia del individuo que habla.

\subsection{Y como no se pudrió...: Blancanieves}

Y como no se pudrió...: Blancanieves nos instala de lleno en el corazón de las tinieblas. Concreta el horror sobre un escenario. Los personajes no son ya europeos sin entrañas que contemplan el espectáculo de la barbarie desde una posición acomodada sino víctimas. Se pone en manos del arte el grito de una niña soldado, una niña violada. Es un grito furioso contra la pobreza y la brutalidad en una región hostigada por la guerra y la hambruna. Es una obra antipolítica en el sentido de que no habla propiamente de política, sino del sufrimiento y la injusticia a que ésta somete a los hombres. En palabras de Hartwig (2006: 213): «El sufrimiento humano es el tema principal [...] la profanación espiritual y corporal de la impunidad, representada en los seres humanos más débiles e inofensivos, los niños».

Según Angélica Liddell, sólo el horror creado nos puede transformar. Hay que inventar el hambre para que sea real; abandonar las imágenes trilladas del horror, domesticadas por los medios de comunicación; huir del tópico, que es lo opuesto al pensamiento y a la invención, y afrontar la denuncia como un reto artístico y estético. Se impone la necesidad de encontrar 
nuevas formas que logren que la información se transforme en dolor; recuperar la tragedia, la catarsis. La palabra - «una palabra que no es reflexiva, sino íntima, desgarrada» (Canale, 2006: 379) - se abre paso en medio de la destrucción de lo real. Liddell vuelve a lo ritual a través de una violencia íntima y poética fundada en la palabra y que apela al sentimiento del espectador, a su fondo irracional; permite ir más allá del sentido, evitando la capacidad de asimilación inmediata que producen las palabras y razones dirigidas sólo a la inteligencia.

El escenario es el lugar-acción, allí donde la palabra se hace visible como un elemento más de la puesta en escena, de un contexto de sucesos, de una pragmática. Liddell sabe bien que el teatro es el arte por excelencia para la expresión de lo humano, convertido en acontecimiento de signo comunitario, físico y sensorial. La palabra queda alumbrada por otros fenómenos como el cuerpo, la acción y la voz. En palabras de Vidal Egea (2011: 297), mediante «la difícil unión entre escritura y acción física llevada al extremo, se consigue un resultado corrosivo de gran potencia». García-Pascual (2012: 34) habla de contrastes efectistas en la obra de Liddell, como el que se da entre el poder y la profanación. Garnier (2012: 125-126) califica su estética de neobarroca y señala que el espacio escénico está fragmentado, «recortado a la vez por la disposición de objetos dispersos (con frecuencia ritualizados), por zonas dibujadas mediante la utilización de la luz y por la forma en la que los actores hacen y deshacen el espacio lúdico en función del ritmo del espectáculo».

La obra que analizamos aquí pertenece a la tercera etapa de la producción de Liddell - con un contenido sociopolítico mucho más explícito que en obras anteriores -, siguiendo la clasificación hecha por Canale (2006: 378). Como señala Cornago (2005: 316), la autora extrema la carga sensorial y sus escenografías se acercan mucho al concepto de instalación. Liddell llega así a un lenguaje de fuerte contenido emocional, cuyo tono visceral y exasperado trata de alcanzar de manera directa la sensibilidad del espectador. Predomina una mirada política donde los protagonistas son despojos de la sociedad del bienestar y las guerras. Con este tipo de teatro, Liddell busca, en palabras de Gutiérrez Carbajo (2006: 106), «devolver a la política su alianza con la filosofía y con la poesía».

En $Y$ como no se pudrió...: Blancanieves, la niña soldado hace una serie de preguntas tomadas de Platón. Los niños del mundo occidental conocen la maldad a partir de relatos de ficción, como el de Blancanieves, mientras que en algunas partes del tercer mundo los niños se relacionan diariamente con el 
mal sin necesidad de fábulas e incluso pactan con él. Veamos lo que dice la autora en el programa de mano de la obra ${ }^{1}$ :

En la cara próspera de la tierra los niños aprenden a relacionarse con el mal a través de los cuentos de hadas, por eso escogimos un personaje infantil centroeuropeo, para encenagarlo en ese lado del mundo donde los niños aprenden a relacionarse con el mal a punta de machete o a cambio de un plato de comida.

La estructura de esta obra - de este poema dramático - se divide en ocho escenas, la última de las cuales equivale a la muerte porque los dos personajes se echan a dormir sabiendo que si lo hacen los fusilarán. Hay siete preguntas y siete escenas; la octava funciona como un epílogo. Aparecen dos personajes, Blancanieves y el soldado, pero éste está escindido entre su rol de interlocutor de Blancanieves y la función narrativa.

Hay en la obra claros referentes culturales, como los caballos de Aquiles - «el mundo yacía mísero, cada vez más, y los caballos de Aquiles seguían llorando por el sufrimiento de los hombres» (Liddell, 2005b: 361) - y, por supuesto, Blancanieves y los siete enanitos - las siete preguntas - . Se da una evidente violación semántica del personaje de cuento de hadas. Tal como anticipa el programa de mano, al personaje se le encenaga en el horror:

BLANCANIEVES.- ;Me pregunto si la vida de una niña vale la pena!

Estaba sola en el inmenso bosque.

Tenía tanto miedo que me he quedado mirando las hojas de los árboles sin saber qué hacer.

[...]

¿Lo escuchas?

Escucha el llanto de las fieras del bosque (Liddell, 2005b: 360-361).

Hay recurrencia a la metáfora animal para expresar la maldad intrínseca a la especie. Es del todo imposible redimirse, a juicio de Liddell. Ante la naturaleza humana se tambalea cualquier tipo de orden social:

SOLDADO.-

En los cuentos siempre hay malos.

${ }^{1}$ www.escenacontemporanea.com $/ 2005 / \mathrm{prg} / \mathrm{g} 15 . \mathrm{htm}$. 
Los buenos y los malos.

Los buenos y los malos.

Los buenos y los malos.

Así que no va a ser difícil matar a nuestros enemigos.

Matar a los malos.

Sólo hay que matar a los malos.

Son niños como tú (Liddell, 2005b: 365).

Asistimos a la mecánica de la repetición, como un sortilegio que va trepando de silogismo en silogismo, en una lógica falsa que nos asoma a las ecuaciones del miedo, del horror, de lo innombrable. Se trata del sistema ritual y mágico de la repetición, con frases sincopadas que se terminan más adelante, tras una interrupción, o que se retoman con variaciones o exactamente iguales. En la escena segunda hallamos la letanía de las siete preguntas:

SOLDADO.- A Blancanieves su abuelo le había enseñado siete preguntas [...] El mundo yacía mísero, dominado por la guerra, como si la civilización estuviera condenada a la peste por desconocer la respuesta a las siete preguntas. Así que Blancanieves le preguntó a un soldado.

BLANCANIEVES.-

¿Qué es el Hombre?

¿Qué es el Estado?

¿Se puede convertir a un hombre en un hombre mejor?

¿Qué es peor, recibir injusticia o cometer injusticia?

¿Existe la verdad?

¿Se puede enseñar la verdad?

Donde está lo bello, ¿el mal desaparece? (Liddell, 2005b: 361).

El soldado responde que el Estado es el insomnio y que el mundo yace mísero, como si la civilización estuviera condenada al hambre por desconocer la respuesta a las siete preguntas. Blancanieves también olvidará las siete preguntas, como consecuencia del dolor, del trauma infligido. Perderá la inocencia y se convertirá en una asesina. El personaje es desplazado, desviado, violado. Desnaturalizado. 
En la escena tercera Blancanieves relata en progresión ascendente el horror de cuanto ha presenciado y que se incrementará todavía más con su propia vivencia en la escena cuarta, narrada con estructura de cuento por el soldado. En la escena quinta el soldado-narrador seguirá contando el cuento de Blancanieves: era tan hermosa que los soldados se la llevaron al comandante como regalo, y se convirtió en la esposa de guerra más bella. En la sexta, el soldado deviene nuevamente interlocutor de Blancanieves y ella se entrena para el horror, para la guerra. En la escena séptima Blancanieves deforma su rostro y su esposo la entrega a los soldados, mucho más brutales que los oficiales. La niña se volverá insensible y sanguinaria: «Ahora era tan fuerte que me podían usar como yunque» (Liddell, 2005b: 369).

En la escena octava habla una voz en off y los dos personajes se disponen a morir. Un cartel remite a la masacre ocurrida en noviembre de 2004 en una escuela de Beslán (Rusia), en que fueron asesinados 171 niños.

Asistimos al horror narrado pero inenarrable. En alguna ocasión ha declarado Liddell que, para ella, existen tres conceptos fundamentales: «la tensión, la metamorfosis y el deseo de los personajes» (Cornago, 2005: 320). La tensión se ha mantenido durante toda la obra, alimentada por el miedo, la amenaza, la culpa. Y al final se ha producido la metamorfosis. Hay un cambio de piel, de naturaleza. Liddell crea belleza a través del dolor, porque la belleza conecta con la verdad. Hay conocimiento y revelación.

\section{EPICIDAD Y PULSIÓN RAPSÓDICA}

En el drama contemporáneo, la voz de los personajes está a menudo deshilachada o es multidireccional - polifónica - y permite la irrupción o el vislumbre alucinado de mundos interiores. La presencia fragmentada de la interioridad (relato de acontecimientos del presente, pasado o futuro, así como de sentimientos y sensaciones) supera la frontera convencional entre lo dramático y lo épico.

Lo épico, en su formulación brechtiana, va unido a la idea de lo racional y lo dialéctico. El propio Brecht (1970, vol. 3: 195) señala que la designación de teatro épico «ha cumplido con su deber al reforzar y enriquecer el elemento narrativo contenido en todo teatro». La epicidad en teatro puede definirse como la tendencia a incorporar elementos épicos y al desarrollo de la narración (y no mera narrativización del drama). Señala Sarrazac (2005: 75) que el teatro épico contemporáneo, desde Piscator y Brecht hasta Müller o Bond, es 
testimonio de conflictos entre intereses, clases, naciones, ideologías, y recuerda al espectador los sufrimientos y acciones de los individuos confrontados a la historia e inscritos en problemáticas económicas, sociales y políticas.

En un teatro epicizado, basado en la narración, por oposición al teatro aristotélico, basado en la acción (según la distinción operada por Brecht, 1970, vol. 1: 126), se introduce discontinuidad, distancia, reflexividad. Al espectador se le impone la necesidad de desvelar, descifrar, interpretar la fábula o la parábola. Lo que sucede en el escenario no es la verdad sino una interpretación de la verdad. Se trata de una mediación necesaria para activar la reflexión y destinada a una hermenéutica que le dé sentido.

Szondi (1994: 150) se refiere al sujeto épico, término que remite a la presencia del autor en la narración, como síntoma de la crisis del drama; Sarrazac (2005: 184) habla más bien de autor rapsoda, por hallar este término más acorde a la escritura contemporánea. Más que muerte del teatro dramático, cabría hablar de hibridaciones de epicidad, dramatismo y lirismo. Sarrazac brinda una definición predominantemente formal del sujeto épico:

Dans tous les cas, le sujet épique introduit une rupture de l'action dramatique telle que l'a définie Aristote dans son principe d'unité, de continuité ou de causalité. La fiction se transforme alors en réflexion. La vision de l'auteur se réfléchit à travers une forme narrative, médiation du sujet épique. Or, cette voix de l'auteur fait appel á un corps étranger pour se faire entendre: corps étranger à l'action dramatique, il l'est aussi face aux protagonistes du drame, puisqu'il est pure parole, pure voix (Sarrazac, 2005: 76).

El término rapsodia - aplicable al drama contemporáneo (Sarrazac, 2005: 183) - procede del griego - raptein significa coser los cantos - y está plenamente vinculado al terreno de la épica homérica. Se trata de un gesto de escritura que da lugar a una nueva distribución de la palabra. Se depone la fábula en favor de técnicas de montaje e hibridación de fragmentos.

Precisamente el relato de vida es una figura básica de la pulsión rapsódica, sea ésta monológica o no. Constituye un recurso epicizador por cuanto presenta y (re)compone la vida de un personaje por medio de la narración pura, y no por medio de un encadenamiento orgánico de acciones. El marco temporal que abarca esta narración puede ser muy amplio. Batlle (2009: 213), sitúa el relato de vida a medio camino entre el impulso épico, la dimensión lírica y el intercambio dramático.

Valentini (1991: 68) introduce el concepto de solo como una consecuencia inevitable de la crisis o el agotamiento del diálogo. Esta figura se halla 
presente en las dramaturgias de Beckett, Bernhard o Müller, entre otros, y tiene que ver con cierta tendencia a trabajar el flujo de la conciencia. El solo consistiría en aquello que no es ni estilo directo libre (monólogo interior literario) ni soliloquio, y que podría relacionarse asimismo con el yo errante de Sarrazac (2005: 186), en el sentido de una voz polifónica que se expresa a mayor profundidad del nivel de lo real.

\subsection{Pulsión rapsódica en Après moi, le déluge}

En Après moi, le déluge, el visitante, el africano, se encarna en el personaje de la intérprete, que se ve transmutada para la ocasión en una suerte de médium. El visitante puede ser real - aunque invisible - o sólo un espíritu; ella, una intérprete o una intermediaria. En cualquier caso, la historia del viejo no suscita la piedad del hombre, sino más bien su irritación, y en la intérprete no queda sino olvido. Europa abusa de los recursos de África y se olvida. Certeramente lo señala Benach (2007: 52) cuando habla de la ausencia de África en los asuntos que conciernen a su propio continente, y también López Rosell (2007: 41), quien apunta que el pueblo africano sólo es el invitado de piedra cuando se debaten asuntos en los que debería tener voz y poder de decisión. Como dice Carlota Subirós, directora del espectáculo, en el dossier de prensa de la obra ${ }^{2}$, el africano, un hombre de un pequeño pueblo del norte del Congo, justo donde Conrad situó El corazón de las tinieblas, es una aparición fulgurante en la imaginación de los demás, una voz que reclama su existencia. Una vindicación de justicia y de dignidad.

En Après moi, le déluge cabe hablar de la gran cantidad de texto referido a África, al Congo de fuera, invisible desde el lujoso hotel destinado a europeos, y también a espacios muy mediatizados por la experiencia temporal y vivencial de los personajes - París, Europa en general-. El universo de la fábula excede al dramático, del que se nutre y al que contiene, y este desajuste se expresa de modo extraordinario en el personaje del africano, supuestamente presente en escena pero invisible para el espectador. Se nos dice que está ahí, pero no está. Habla a través de la voz de otro personaje, el de la intérprete, que sí está en escena y le sirve para materializarse. La existencia del personaje africano en el drama pasa por una suerte de vampirización, por un anonadamiento o disolución en el personaje de la intérprete; su presencia corpórea no es ofrecida al espectador.

\footnotetext{
${ }^{2}$ http://www.mcu.es/principal/docs/novedades/2008/le_deluge.pdf.
} 
En este caso, el elemento ausente - ausente como corporeidad autónoma pero escénicamente presente en virtud de la transubstanciación de la intérprete - se convierte en el centro temático del drama: el africano viejo como personaje, como víctima, y también como metáfora de la invisibilidad de África. También mediante su discurso, el tiempo ausente - evocado y, en definitiva, manipulado o falseado de la experiencia del hombre africano y de su hijo- y el espacio ausente, el del poblado y la milicia que discurre fuera de las paredes del confortable hotel donde tiene lugar la conversación, cobran más fuerza e importancia que el tiempo y el espacio presentes. Un no-lugar «caracterizado por la indeterminación y la relatividad» (Lorenzo Zamorano, 2005: 455) y un tiempo extrañado: «un presente irreal, descarnado, que funciona como por poderes, a través de intermediarios» (Garnier, 2005: 204).

En Après moi, le déluge, la habitación de hotel es el espacio propio del hombre de negocios y la intérprete, ambos blancos. Cuando irrumpe un personaje impropio de este espacio físico, y en realidad también ajeno al espacio psíquico de los otros dos personajes, no llega a tomar cuerpo a los ojos de quienes lo miran; su condición de existencia es la invisibilidad. No nos llega ni su voz ni su cuerpo, porque en el espacio-estado que habitamos no somos capaces de verlo. Todo llega en diferido, mediatizado. La invisibilidad es una metáfora, una proyección simbólica del espacio que NO ocupa el personaje del africano viejo. No es posible concebir África, verla, desde un lugar destinado a europeos acomodados, ni en un hotel de la capital congoleña ni en un escenario de teatro. La ausencia de África va más allá del fuera de escena, de lo extraescénico; se adentra en el ámbito de la conciencia y de la moral.

De este modo, con una escenografía minimalista y con dos actores en escena, Cunillé transmite de modo altamente eficaz su mensaje. El tono es ominoso, pero en sordina, «agazapado en la vibración profunda de la obra y no con la envoltura del rutinario discurso tonante-humanitario que suele utilizarse para agitar la mala conciencia de la sociedad opulenta» (García Garzón, 2008: 88).

Cunillé debe lograr interesar con el relato del viejo africano al traficante y también al espectador, y señala Ordóñez (2007: 36) que lo hace por medio del sistema más antiguo y más efectivo: contando una buena historia, con sucesivas incógnitas e imprevisibles revelaciones. Se recurre así a lo narrativo, al resorte épico. Se despliega un discurso hipnótico, recurrente, machacón, con la finalidad de captar la atención del traficante y del público. Hay un recurso a lo oracular, a lo pítico, al trance de la posesión. 
Batlle (2009: 213) pone como ejemplo esta obra de Cunillé para avalar su tesis de que en el drama contemporáneo la rapsodia está a la orden del día. La escisión del sujeto se resuelve dramática y escénicamente en una total abducción: la traductora acaba asumiendo la identidad del traducido. La extensa explicación del hombre africano, que pide al hombre de negocios que se lleve a su hijo a Europa y se erige así en mensajero de los deseos del hijo, remite a la pulsión rapsódica y constituye un auténtico relato de vida.

Sarrazac (2005: 177) define el relato de vida como un recurso fundamentalmente épico, pero fuertemente vinculado también a la subjetivización moderna del drama. El relato del personaje opera como un filtro, propone una versión de los hechos, se organiza en pos de un sentido. Por una parte, orienta la temporalidad hacia la retrospección; por otra parte, cuestiona el estatus o la entidad del personaje, que adquiere una dimensión espectral, de muerto en vida. La acción se convierte en descripción; el personaje queda reducido a una voz. A eso se debía estar refiriendo Subirós ${ }^{3}$ cuando hablaba de psicomaquia o lucha de almas en esta obra. Y es que la obra habla de niños soldados, pero también de padres e hijos, y de los espíritus del África invisible (Ordóñez, 2007: 36). A lo largo del relato del africano, y también de la conversación entre los europeos, afloran voces sepultadas e imágenes confusas del pasado, de lo ido. Porque, paralelamente al relato de vida, está lo no-dicho, la representación del silencio, la intuición de lo no expresado, del mundo psíquico oculto, la confesión lacerante, el recuerdo incierto. Como señala García-Pascual (2011: 350), «En la escena se actúa y se habla, pero también se retrata físicamente el silencio». El ritmo del texto se apoya en un diálogo fluido y jalonado de silencios y pausas, que, además de operar como transición para que la intérprete asuma la voz del otro, confieren a la conversación naturalidad y sugieren el horror no dicho.

El africano topa con los límites del silencio: las réplicas esquivas de su interlocutor son como una puerta cerrada, y su propio relato está al borde de la inexistencia: primero, porque el personaje es invisible, tanto a nivel de texto como a nivel de puesta en escena, y segundo, porque el relato que cuenta acerca del hijo que debe irse a Europa se revela falso - el hijo murió hace tiempo - . El discurso interior, individual, no alcanza exterioridad o repercusión en los demás personajes, por las características del propio emisor y del interlocutor - incluso de la intermediaria-. Pero la pulsión rapsódica concretada en el africano invisible permite apelar a la conciencia del espec-

${ }^{3}$ Véase nota 2. 
tador, en la medida en que incide en una realidad social y política. Lejos del valor documental, lejos de la ilusión de un testimonio en directo, el relato del africano invisible alcanza un valor poético y propone una hermenéutica.

El personaje es una suerte de placa reflectora, se aferra a la narración que trata de explicar pero se le escapa. Mediante este resorte narrativo conocemos la situación del africano, tratamos de reconstruir su identidad minada. El relato está templado por el embate de la lengua, exhalación fuertemente ligada al cuerpo. Es la palabra de la supervivencia, del grito y de la angustia, si bien un grito en forma de relato, de relato mixtificado. Esta palabra de la supervivencia se encarna en otro, la intérprete-médium, personaje que registra una difícil metamorfosis. En este sentido, declara Subirós ${ }^{4}$, que «el compromiso ético profundo de esta pieza se convierte en su forma» y en el juego que propone a sus actores.

\subsection{Epicidad y solo en $Y$ como no se pudrió...: Blancanieves}

El poema dramático, subgénero en que puede inscribirse $Y$ como no se pudrió...: Blancanieves, es una forma de emancipación del drama absoluto -y de una concepción ilusionista del teatro - y puede, en este sentido, compararse al drama rapsódico que analiza Sarrazac (2005: 183-187). Experimental y abierto, lírico y sugestivo, hibrida las formas y apela furiosamente a la conciencia del espectador. El poema dramático de Liddell mantiene la división en escenas, aunque se trata en realidad de una yuxtaposición de monólogos, pues el diálogo propiamente dicho ha desaparecido. Se alternan monólogos, silencios e intervenciones plásticas y musicales. Se explora y explota el poder de la palabra sin desatender la materialidad escénica. La forma del poema dramático se revela idónea para encauzar la reflexión de Liddell sobre hechos que están pidiendo a gritos el lenguaje.

Liddell reconoce la relación del teatro con algo muy antiguo, con el canto épico y la tradición oral (Cornago, 2005: 31). La linealidad narrativa permite la eclosión de la palabra y del cuerpo como acontecimiento. La palabra reasume el mito; el cuerpo es el lugar del sacrificio ritual, de la expiación. Señala Cornago (2005: 67) que «La dimensión lineal y progresiva del mito se traduce en un plano performativo que vive en el tiempo de la repetición [...] A la palabra como mito se le añade, en un juego de contrastes, la palabra como ritual, repetición y realización física».

${ }^{4}$ Véase nota 2. 
El teatro de Liddell parte de la indignación y es un ajuste de cuentas, en este caso a través de un cuento de hadas corrompido, de una fábula lacerante. El soldado asume la función épica, de narrador, ya desde la escena primera — «Cuando la niña cumplió doce años hacía dos que había empezado la guerra. [...] Las guerras son como las madrastras perversas. Todas quieren ser las más bellas. Todas se miran en el espejo de otra guerra» (Liddell, 2005b: 359-360) - , y se desdobla en personaje - representante del Estadoy narrador en parlamentos sucesivos al final de la escena segunda:

SOLDADO.-

El Estado es el insomnio,

usted no ha venido aquí a dormir,

esto no es un hotel

[...]

SOLDADO.- El mundo yacía mísero, cada vez más, como si la civilización estuviera condenada al hambre por desconocer la respuesta a las siete preguntas. Condenada al hambre (Liddell, 2005b: 362).

Si el soldado hace las veces de interlocutor o de narrador, porque está escindido, Blancanieves realiza solos, como forma de monólogo desviado que no aspira al debate sino que se afirma en un universo cerrado en la medida en que faltan relaciones dialógicas directas. En la escena tercera asistimos al solo, al flujo de conciencia - con libre asociación temática y sintáctica- de una princesa de cuento mancillada, encenagada, corrompida. Tras su confrontación con el hambre y el dolor, Blancanieves se dirigirá al soldado para formularle una petición: «Mi padre me contaba cuentos de hadas / para enseñarme lo que era el mal. / Y al final siempre me casaba con el Príncipe. / Y tú, tú, ¿me cuentas tú un cuento de hadas?» (Liddell, 2005b: 363).

$\mathrm{Su}$ intento de entrar en contacto con el mundo, o de restablecer el antiguo código de cuento de hadas, será brutalmente ignorado, cruelmente castigado por la incongruencia con el ambiente circundante. El soldado responderá a su petición con un cuento, la narración que da inicio a la escena cuarta, como un preludio a la expresión más salvaje de la intimidad, subjetividad e interioridad de la niña:

SOLDADO.- Y como no se pudrió, un grupo de soldados la encontró tirada en el bosque. Los soldados eran jóvenes y fuertes y tenían el corazón tan velludo como sus brazos. Y la violaron doce veces, una vez por cada año de vida de la 
niña. Y Blancanieves por fin abrió los ojos, después de muerta, como si cada soldado hubiera sido un Príncipe, como si cada violación hubiera sido un beso, como si cada vez que la habían llamado puta la hubieran resucitado (Liddell, 2005b: 363).

En la escena sexta, el soldado vuelve a ser el interlocutor de Blancanieves y la inicia en el aprendizaje de la guerra. «No va a ser difícil. / Las niñas lo aprendéis todo en los cuentos [...] Sólo hay que matar a los malos» (Liddell, 2005b: 365). Después de este parlamento, el soldado inicia otro como narrador. Nos cuenta cómo por las noches drogaban a la niña y la dejaban delirar frente al televisor. A continuación Blancanieves desgranará un solo, muestra de su delirio.

Valentini (1991: 73) señala que la dramaturgia contemporánea expresa un estadio infantil del conocimiento en que la pregunta por qué manifiesta una actitud auroral de descubrimiento del mundo, con la diferencia de que no hay adultos que puedan facilitar las respuestas. El mal es tan absoluto que niega toda posibilidad de sentido, de respuesta: «Quiero sentirme como algo no humano /y me afeito la garganta como si fuera un lobo [...] Ayer me harté de romper huesos y carne / con una fuerza más antigua que el diluvio [...] ¿Qué habéis hecho con mi bondad?» (Liddell, 2005b: 366-367).

En la escena octava no se recurre al soldado como narrador sino a una voz en off. La voz en off, en palabras de Angélica Liddell, «tiene que ver tanto con la omnisciencia como con la inconsciencia. Por supuesto, está relacionada con el relato, con el érase una vez. Es una forma también de utilizar el contrapunto» (Cornago, 2005: 322). He aquí la voz en off del final de la obra:

VOZ EN OFF.-

A las armas

Todos los niños a las armas.

[...]

Los niños que no cojan las armas serán fusilados.

Los niños que duerman serán fusilados.

El SOLDADO y BLANCANIEVES se visten con pijamas y se echan a dormir (Liddell, 2005b: 369).

Con frecuencia, en el drama contemporáneo el sujeto se desarticula, se escinde, se multiplica, deviene poliédrico o simplemente desaparece, y con él 
la fábula, por la tensión entre el yo y un mundo incomprensible e inalcanzable. Esa polifonía extrañada tiene que ver con la destrucción de las categorías espaciotemporales. La propia Liddell (2005a: 67-68) brinda una explicación razonada de la dinamitación del espacio y el tiempo teatrales: «La definición del sufrimiento usurpa la definición del espacio y del tiempo. El sinsentido alcanza a la definición de las dimensiones espaciotemporales dando lugar a fórmulas aberrantes y nihilistas». Ello implica la reafirmación feroz del individuo que se traduce en subjetividad absoluta y en confusión de autor/personaje.

Frente a la guerra, cualquier argumento palidece. El personaje se hace a un lado, pierde consistencia. Refugiarse en la ficción es imposible; se ha vuelto impotente, incapaz de explicar el mundo. Hay una focalización en el individuo para escapar de la masacre, de la fosa común. El dolor íntimo, individual, parece lo único capaz de dar cuenta de la realidad. La obra se revela contra el poder y la muerte indiscriminada (Liddell, 2005a: 67-75).

Apunta Valentini (1991: 88) que el espectáculo contemporáneo no representa el tiempo en transformación y desarrollo, sino un tiempo inconmensurable, absoluto, como el épico, donde no se hace sino contemplar lo que ya ha tenido lugar. Tiene que ver con lo que dice Liddell en la entrevista radiofónica para La Casa Encendida (2005) ${ }^{5}$ : «La obra bien pudiera ser un recuerdo de los desastres de la guerra, después de la batalla [...] la parte podrida de las cosas [...] lo que ha sucedido desde el recuerdo». El espacio es una ruina, el tiempo es un cadáver. El único compromiso posible es con el sufrimiento humano, desubicado e intemporal, esto es, ubicuo y eterno. La tragedia es ya ininterrumpida. La desdicha lo cubre todo. Cornago (2005: 63) habla de «la eternidad mítica del tiempo presente del horror».

Decía Brecht que para contribuir a la mejora del espectador, del individuo, el teatro debe proporcionar algo más que inmersión emocional, porque la sola emoción produce inmovilidad resignada y aceptación; debe valerse de la razón, no renunciar a ella, para promover una actitud receptiva y con ella el cuestionamiento de la realidad.

Liddell apela a la emoción con el cuerpo, que es sacrificial siempre, y con la palabra, que es portadora - además de lirismo y emoción - de razón y dialéctica. Liddell reúne en su teatro legados tan dispares como puedan ser

${ }^{5}$ http://www.lacasaencendida.es/Ficheros/CMA/ficheros/capsula_no_pudrio_blancan.MP3. 
el de Brecht - el teatro como forma de conocimiento promotora de una metamorfosis a largo plazo - y el de Artaud - lo ritual, lo sacrificial-. Y cabría añadir, entre otros, a Grotowsky, Beckett y Müller. Con la puesta en escena - y la dimensión física de la palabra - remite al rito, a lo sacrificial, y apela a las vísceras, a lo emocional; con su recurso a la epicidad, al solo, al relato de vida, al logos, apela al pensamiento. «El arte — declaraba Liddell a propósito de este espectáculo $0^{6}$ - debe aliarse con el pensamiento para conducir al espectador hacia un conocimiento».

\section{CONCLUSIONES}

Señala Batlle (2009: 204) que la confluencia de elementos épicos y de elementos íntimos está en la raíz misma de la dramaturgia moderna. Permiten acceder a una versión de la verdad, asumir una perspectiva distanciada de lo real. Lo narrativo o lo épico suele asociarse al distanciamiento, pero ello no es incompatible con lo íntimo ni con la emoción. Este proceso dialéctico entre lo épico y lo íntimo es perceptible en las dos obras estudiadas, si bien a través de procedimientos y estilos radicalmente distintos.

En Après moi, le déluge, los personajes se proyectan - desde un estatismo de espacio interior - en la palabra hablada. La acción viene dada por la palabra, que vehicula la memoria intermitente, las impresiones fragmentarias, el carácter inaprensible del tiempo y de la experiencia. Y, por supuesto, la voluntad inquebrantable del personaje invisible, el africano viejo, de despertar la conciencia o, cuando menos, de incomodar a los europeos que se hospedan en su país arrasado como si se tratara de un balneario o un solárium a la medida de sus necesidades e indolencia. En este personaje se concreta el resorte épico, el sujeto rapsódico que recurre a un discurso hipnótico, de extraña circularidad.

El relato de vida construye un pasado, una vida, avanza y retrocede para acabar realizando una pirueta final que invalide la veracidad del enunciado pero exalte la verdad intrínseca del referente real que es punto de partida. Desde la vacuidad y el inmovilismo, los personajes europeos se proyectan o se refugian - en un movimiento retrospectivo que hace más habitable el presente- en tiempos que no existen ya. Todo se resuelve sin estridencias, en una apuesta más o menos convencida por la supervivencia.

${ }^{6}$ Véase nota 5. 
En otro orden de cosas, los personajes de Angélica Liddell se definen ante todo por su condición de supervivientes, capaces de habitar sin naturaleza, sin lugar. Los lugares no existen ya, han sido destruidos, junto con la duración de las cosas; los lugares son apenas ruinas de una civilización donde es imposible ubicar la acción ni la palabra. Un personaje de cuento de hadas corrompido desgrana un solo devastador sobre la maldad y el dolor. La masacre anula la identidad.

El sutil trazo de Cunillé contrasta vivamente con el violento despliegue verbal de Liddell, que no atañe sólo a la función narrativa, sino que adquiere una dimensión física y produce un fuerte impacto emocional. Liddell articula una estructura narrativa con aliento poético; toma prestada la estructura del cuento tradicional y siembra el horror para que el espectador se conmueva y no digiera impasible las noticias de la catástrofe. Y le añade poesía, arte, belleza. En palabras de Liddell: «No es que te deleites en el horror, sino que se trata de utilizar lo bello para transmitirlo [...] el teatro es ese espacio de reflexión que admite la belleza y la poesía» (Cornago, 2005: 325). Una belleza terrorífica y capaz de conducir al conocimiento.

¿Es el arte capaz de mover a la transformación? Para Liddell, el arte es capaz de sensibilizar, de generar compasión, de activar la conciencia individual. Con todo, la propia intención de denuncia la contraría por cuanto le otorga un rol aleccionador que le disgusta, y rehúye furiosamente el tópico. Tampoco Cunillé parece sentirse cómoda desde un compromiso explícitamente asumido, desde el documento sociológico o el discurso humanitario; tal vez por ello construye su denuncia haciendo visible la invisibilidad.

Por un lado, la ausencia de cuerpo del personaje africano en Après moi, le déluge; por el otro, el cuerpo sobreexpuesto y sacrificial en $Y$ como no se pudrió...: Blancanieves. El misterio por omisión y el misterio desde el exceso. Recursos extremos - antitéticos - que apelan a la conciencia del espectador y demandan una clave hermenéutica.

\section{REFERENCIAS BIBLIOGRÁFICAS}

BARBERO REVIEJO, T. (2005). «Espacios íntimos en la dramaturgia de Lluïsa Cunillé». En Dramaturgias femeninas en la segunda mitad del siglo XX: espacio y tiempo, José Romera Castillo (ed.), 271-281. Madrid: Visor Libros. 
BATLLE, C. (2009). «Postfaci. Apunts sobre la pulsió rapsòdica en el drama contemporani». En Lèxic del drama modern i contemporani, Jean-Pierre Sarrazac (ed.), 203-235. Barcelona: Institut del Teatre.

BENACH, J.-A. (2007). «África, un viejo dolor». La Vanguardia, 15 de diciembre, 52.

BRECHT, B. (1970). Escritos sobre teatro, 3 vols. Buenos Aires: Ediciones Nueva Visión.

CANALE, M. (2006). «Forma y política en el teatro de Angélica Liddell». En Tendencias escénicas al inicio del siglo XXI, José Romera Castillo (ed.), 369-382. Madrid: Visor Libros.

CORNAGO, Ó. (2005). Políticas de la palabra: Esteve Grasset, Carlos Marqueríe, Sara Molina y Angélica Liddell. Madrid: Espiral/Fundamentos.

CUNILlÉ, L. (2011). Après moi, le déluge. En Dramaturgas españolas en la escena actual, Raquel García-Pascual (ed.), 185-247. Madrid: Castalia.

GARCÍA GARZÓN, J. I. (2008). «Sol negro». ABC, 5 de junio, 88.

GARCÍA-PASCUAL, R. (2012). «Protocolo de valoración del código de comunicación grotesco en las creadoras teatrales (siglos XX y XXI): teoría y práctica escénica». Signa 21, 13-54.

GARCÍA-PASCUAL, R. (ed.) (2011). Dramaturgas españolas en la escena actual. Madrid: Castalia.

GARNIER, E. (2005). «Lluïsa Cunillé: El instante de la muerte o la muerte del instante». En Dramaturgias femeninas en la segunda mitad del siglo XX: espacio y tiempo, José Romera Castillo (ed.), 195-209. Madrid: Visor Libros.

- (2012). «El "espíritu de lo grotesco" en el teatro de Angélica Liddell». Signa 21, 115-136.

GUTIÉRREZ CARBAJO, F. (2006). Seis manifestaciones artísticas. Seis creadoras actuales. Madrid: UNED.

HARTWIG, S. (2006). «Ante los monstruos: la "estética de feria" en el teatro contemporáneo». En Tendencias escénicas al inicio del siglo XXI, José Romera Castillo (ed.), 211-223. Madrid: Visor Libros.

LIDDELL, A. (2005a). «Un minuto dura tres campos de exterminio: la desaparición del espacio y del tiempo». En Dramaturgias femeninas en la 
segunda mitad del siglo XX: espacio y tiempo, José Romera Castillo (ed.), 67-75. Madrid: Visor Libros.

- (2005b). Y como no se pudrió...: Blancanieves. En Políticas de la palabra: Esteve Grasset, Carlos Marquerie, Sara Molina y Angélica Liddell, Óscar Cornago (ed.), 357-369. Madrid: Espiral/Fundamentos (también en http://artes escenicas.uclm.es/archivos_subidos/textos/163/AngelicaLiddell-Ycomonosepudrio-Blancanieves.pdf).

LÓPEZ ROSELL, C. (2007). «Al cor de l'Àfrica». El Periódico, 17 de diciembre, 41.

LORENZO ZAMORANO, S. (2005). «Heterotopías femeninas: análisis del espacio teatral en clave neomoderna». En Dramaturgias femeninas en la segunda mitad del siglo XX: espacio y tiempo, José Romera Castillo (ed.), 453-464. Madrid: Visor Libros.

ORDÓÑEZ, M. (1998). «Aprengui a estimar la tònica». Avui, 23 de marzo, 43.

- (2007). «Una Beretta con una sola bala». El País, 29 de diciembre, 36.

PUCHADES, X. (2005). «Cunillé, mapa de sombras». Pausa 20, 18-33.

ROMERA CASTILLO, J. (2011). Pautas para la investigación del teatro español y sus puestas en escena. Madrid: UNED.

ROMERA CASTILLO, J. (ed.) (2005). Dramaturgias femeninas en la segunda mitad del siglo XX: espacio y tiempo. Madrid: Visor Libros.

- (2006). Tendencias escénicas al inicio del siglo XXI. Madrid: Visor Libros.

- (2011). El teatro breve en los inicios del siglo XXI. Madrid: Visor Libros.

SARRAZAC, J.-P. (ed.) (2005). Lexique du drame moderne et contemporain. Belval: Circé.

SZONDI, P. (1994). Teoría del drama moderno (1880-1950). Tentativa sobre lo trágico. Barcelona: Destino.

VALENTINI, V. (1991). Després del teatre modern. Barcelona: Institut del Teatre.

VIDAL EGEA, A. (2010). El teatro de Angélica Liddell (1988-2009). Tesis doctoral dirigida por Francisco Gutiérrez Carbajo y defendida en la UNED. Inédita hasta el momento, se puede consultar en línea: http://info.uned.es/centro-investigacion-SELITEN@T/pdf/TESIS_ ANA_VIDAL_SOBRE_LIDDELL.pdf. 
- (2011). «Las Acciones en el teatro de Angélica Liddell». En El teatro breve en los inicios del siglo XXI, José Romera Castillo (ed.), 289-297. Madrid: Visor Libros.

Recibido el 13 de mayo de 2012.

Aceptado el 30 de septiembre de 2012. 
